\title{
"The impact of the supervisory board on bond ratings of non-financial companies"
}

\begin{tabular}{|c|c|}
\hline AUTHORS & $\begin{array}{l}\text { Zainal Abidin Sahabuddin } \\
\text { Bram Hadianto (D) https://orcid.org/0000-0001-9140-3216 }\end{array}$ \\
\hline ARTICLE INFO & $\begin{array}{l}\text { Zainal Abidin Sahabuddin and Bram Hadianto (2020). The impact of the } \\
\text { supervisory board on bond ratings of non-financial companies. Investment } \\
\text { Management and Financial Innovations, 17(1), 15-23. } \\
\text { doi:10.21511/imfi.17(1).2020.02 }\end{array}$ \\
\hline DOI & http://dx.doi.org/10.21511/imfi.17(1).2020.02 \\
\hline RELEASED ON & Thursday, 06 February 2020 \\
\hline RECEIVED ON & Tuesday, 01 October 2019 \\
\hline ACCEPTED ON & Tuesday, 10 December 2019 \\
\hline LICENSE & $\begin{array}{l}(c) \overline{E Y} \\
\text { This work is licensed under a Creative Commons Attribution } 4.0 \text { International } \\
\text { License }\end{array}$ \\
\hline JOURNAL & "Investment Management and Financial Innovations" \\
\hline ISSN PRINT & $1810-4967$ \\
\hline ISSN ONLINE & $1812-9358$ \\
\hline PUBLISHER & LLC "Consulting Publishing Company "Business Perspectives" \\
\hline FOUNDER & LLC "Consulting Publishing Company "Business Perspectives" \\
\hline
\end{tabular}

NUMBER OF REFERENCES

37
NUMBER OF FIGURES

1
NUMBER OF TABLES

6

(C) The author(s) 2023. This publication is an open access article. 


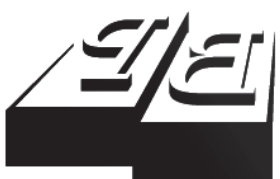

BUSINESS PERSPECTIVES

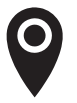

LLC "CPC "Business Perspectives" Hryhorii Skovoroda lane, 10, Sumy, 40022, Ukraine

www.businessperspectives.org

Received on: $1^{\text {st }}$ of October, 2019 Accepted on: 10 ${ }^{\text {th }}$ of December, 2019

(c) Zainal Abidin Sahabuddin, Bram Hadianto, 2020

Zainal Abidin Sahabuddin, Dr. Lecturer, Faculty of Defense Management, Department of Defense Economics, Indonesia Defence University, Jakarta, Indonesia.

Bram Hadianto, Dr., Faculty of Economics, Department of Management, Maranatha Christian University, Bandung, Indonesia.

\section{(c) (i)}

This is an Open Access article, distributed under the terms of the Creative Commons Attribution 4.0 International license, which permits unrestricted re-use, distribution, and reproduction in any medium, provided the original work is properly cited.

\section{THE IMPACT OF THE SUPERVISORY BOARD ON BOND RATINGS OF NON-FINANCIAL COMPANIES}

\begin{abstract}
Issuing bonds is one of the alternative ways for non-financial companies to get money from the public besides borrowing money from banks. Compared with getting money banks, obtaining money from the bond market is slightly economical because the companies are not essential to borne the intermediation cost anymore. As a consequence, the companies in the bond market will get the assessment from the appointed agency. Furthermore, the rating of bonds will determine their reputation.
\end{abstract}

Mentioning the literature review, the bond ratings are affected by the features of the supervisory board: size, independence, and audit committee. Therefore, this research intends to attain two goals. Firstly, it aims to prove and analyze the impact of the supervisory board size and independence, as well as the audit committee size on the company's possibility to get a high bond rating with profitability as the control variable. Secondly, it intends to know the accuracy rate of grouping the company bond ratings through the classification matrix.

The population originates from the non-financial companies. The total samples are determined by the Slovin formula with a boundary of the fault of $10 \%$. Based on this formula, the total samples are 36 companies. Furthermore, they are randomly grabbed from the population. The ordered probit regression model and the classification matrix are utilized to analyze the data.

Based on the data analysis, this research finds out that the supervisory board size and independence, the audit committee size, and profitability positively affect the bond ratings. It means that the number of the commissioner board and the members of the audit committee have to be added until achieving the maximum level to monitor the performance of the directors so that the company can reach a high bond rating. To sum up, board governance is effective in improving the company's bond rating.

\section{Keywords}

audit committee size, bond rating, non-financial companies, profitability, the supervisory board size, independence

JEL Classification G24, G32, G34

\section{INTRODUCTION}

The assets are the resource of the firm to generate cash flow (Brealey, Myers, \& Allen, 2006). They must be fixed assets because they can create profits (Gitman \& Zutter, 2012) to the shareholders as the firm owners (Ehrhardt \& Brigham, 2012). The determination of these types of fixed assets that companies invest and the ways to get profits becomes the responsibility of the financial managers (Brealey et al., 2006). To obtain it, they have to seek for an inexpensive source of funds at the convinced risk (Hanafi, 2017).

According to the pecking order theory, as disclosed by Brealey et al. (2006), using the debt is the second sequence if the retained earnings of the firms are not adequate to finance the available projects. The source of debt can be from a bank and a capital market. If the firms choose the loans from the bank, they have to endure the intermediary cost (the difference in the lending rate and the deposit rate), which is 
more expensive than the issuing bonds in the capital market. On the other hand, if they issue bonds, they do not pay this intermediary cost (Husnan, 2009). The firms deciding to issue bonds are mandatory to be monitored and evaluated by the government-appointed rating agencies (Hartono, 2017), such as KASNIC Credit Rating and PEFINDO in Indonesia (Marfuah \& Endaryati, 2016).

From previous literature, firm governance is vital to raise the bond rating. The mechanism of this governance covers the role of the supervisory board reflected by its size (Setyaningrum, 2005; Aman \& Nguyen, 2013; Altwijry, 2015; Zemzem \& Zouhari, 2016; Elhaj, Muhamed, \& Ramli, 2017), its independence (Bhojraj \& Sengupta, 2003; Ashbaugh-Skaifea, Collins, \& LaFond, 2006; Grassa, 2016; Marfuah \& Endaryati, 2016; Mariana, 2016), and the presence of individuals becoming the audit committee (Setyaningrum, 2005; Syakhroza, 2005; Rianingsih, 2009; Marfuah \& Endaryati, 2016).

Unfortunately, the results of previous research related to the impact of board size on the bond rating are still arguable. For example, Setyaningrum (2005), Aman and Nguyen (2013), Elhaj et al. (2017) find a positive impact. On the other hand, Altwijry (2015), Zemzem and Zouhari (2016) discover a negative. Meanwhile, Sareen and Vij (2015), Grassa (2016), Marfuah and Endaryati (2016), as well as Mariana (2016) fail to prove this impact.

The impact of supervisory board independence on bond rating also shows similar results. The results of this impact can be positive (Bhojraj \& Sengupta, 2003; Ashbaugh-Skaifea et al., 2006; Grassa, 2016), negative (Marfuah \& Endaryati, 2016; Mariana, 2016). Meanwhile, Aman and Nguyen (2013), Sunarjanto and Tulasi (2015), Altwijry (2015), Zemzem and Zouhari (2016), Elhaj et al. (2017) are not successful to show this impact.

The contradictory impacts of committee audit size on the bond rating also still exist. This condition stands for the research illustrating a positive impact (Setyaningrum, 2005; Rianingsih, 2009; Marfuah \& Endaryati, 2016) and the absent impact (Sareen \& Vij, 2015; Mariana, 2016).

Because the previous research evidence does not yield the consensus yet, the research with the probit regression model is essential to do. The use of this model because of the ability to estimate the regression coefficients (Widarjono, 2013) and to get the accuracy rate of grouping the bond ratings through the classification matrix (Gray, Mirkovic, \& Ragunathan, 2006). Hence, this study intends to examine and analyze the impact of supervisory board size and independence, audit committee size on company possibility to get a high bond rating, and know the accuracy rate of categorizing the bond rating through the classification matrix.

\section{LITERATURE REVIEW}

The company with good governance can assure the return of the invested money to their providers (Shleifer \& Vishny, 1997): dividends to shareholders (Mitton, 2004), interest and principal to banks (Gitman \& Zutter, 2012), coupon and the principal to bondholders (Tandelilin, 2010). To implement good governance, the company issuing the bonds needs to control top management (Abor, 2007) by appointing the supervisory board (Tjager, Alijoyo, Djemat, \& Soembodo, 2003). The following section discusses the role of the supervisory board and its components with the bond rating.
Indonesia adopts the dual board system. As a consequence, the commissioner board and director board exist in the companies (Tjager, Alijoyo, Djemat, \& Soembodo, 2003). In Indonesia, the board of commissioners and directors is appointed based on the decision of the general meeting of shareholders (Syakhroza, 2005). Furthermore, the board of commissioners supervises the board of directors (Sukamulja, 2004). The effectiveness of the supervisory board depends on the number. The resource dependence theory argues that a large number of the supervisory board consisting of many experts is needed to give advice to the board of directors to improve the company's per- 
formance (Pfeffer, 1972). According to the study of Setyaningrum (2005), Aman and Nguyen (2013), Elhaj, Muhamed, and Ramli (2017), this condition will make the company to get a high bond rating status. Based on this information, the first research hypothesis is as follows:

H1: The supervisory board's size has a positive impact on the company's possibility to get a high bond rating.

The presence of individuals becoming the independent supervisory board uses to create the virtuous monitoring of the board of directors (Bhojraj \& Sengupta, 2003). Through it, directors are prevented from investing the money from the issued bonds on hazardous projects that the controlling shareholders like (Easterbrook, 1984) or distribute the cash from the issued bonds as dividends to the firm shareholders (Kalay, 1982). If this prevention is successful, the risk of outstanding bonds will decline so that the firm bond rating status will improve as Bhojraj and Sengupta (2003), AshbaughSkaifea, Collins, and LaFond (2006), and Grassa (2016) declare. According to this information, the second research hypothesis is as follows:

H2: The independence of the supervisory board has a positive impact on the company's possibility to get a high bond rating.

An audit committee is made by the supervisory board to ensure that board directors already implement the transparency and disclosure principle consistently (Tjager et al., 2003). Two principles intended are related to the accuracy of financial information delivered to its users. If this committee can function properly, the deduction of the opportunistic behavior of the board of directors happens (Ashbaugh-Skaifea et al., 2006). After that, the quality of financial statement reporting increases; hence, the issuers of bonds will have a low default risk and the improvement of their rating status (Setyaningrum, 2005; Ashbaugh-Skaifea et al., 2006). The effectiveness of the audit committee to do this function depends on the number of individuals in this position (Setyaningrum, 2005). The research of Setyaningrum (2005), Rianingsih (2009), and Marfuah and Endaryati (2016) affirms that the bigger the number of individuals in the audit committee, the better the bond rating status.
According to this information, the third research hypothesis is as follows:

\section{H3: Audit committee's size has a positive impact on the company's possibility to get a high bond rating.}

Following Setyaningrum (2005), AshbaughSkaifea et al. (2006), Rianingsih (2009), Aman and Nguyen (2013), Zemzem and Zouhari (2016), Elhaj et al. (2017), the position of profitability in this research is as the control variable. Profitability is the ability of the company to sustain its business continually. For bond issuers, this ability will reduce its default risk and upgrade their rating (Purwaningsih, 2008). The study of Setyangrium (2005), Ashbaugh-Skaifea et al. (2006), Purwaningsih (2008), Hadianto and Wijaya (2010), Aman and Nguyen (2013), and Sunarjanto and Tulasi (2013) confirms. According to this information, the fourth research hypothesis is as follows:

H4: Profitability has a positive impact on the company's possibility to get a high bond rating.

\section{RESEARCH METHOD}

The population of this research is the non-financial companies issuing the bonds until June 2018 with a total of 56 . Since one company does not have a rating, it is removed from the population so that the relevant population $(N)$ consists of 55 . To get the representative total samples $(n)$, the formula of Slovin with the boundary of the fault of $10 \%$ is used. By using it, the number of samples $(n)$ is

$$
\frac{N}{1+N e^{2}}=\frac{55}{1+55(10 \%)^{2}}=35.5 \approx 36 \text {. }
$$

Furthermore, 36 companies are grabbed from the population by the simple random sampling method, and their names are presented in Appendix A. To get the information about them, the data are collected by the archival method. According to Hartono (2012), this method gathers secondary data. The data intended, moreover, come from the Indonesia Bond Market Directory (IBMD) 2018-2019. 
Variable is the concept that has a variety of values (Sugiyono, 2012). The definition of this research variable is in Table 1.

Table 1. Description to measure research variables

\begin{tabular}{|c|c|c|}
\hline Variables & Description & Scale \\
\hline $\begin{array}{l}\text { The company's } \\
\text { bond rating }(B R)\end{array}$ & $\begin{array}{l}\text { The bond rating of the company in } \\
\text { July } 2018 \text {. Point } 5 \text { is for the company } \\
\text { with grades } A A A \text { and } A A A \text {. Point } 4 \\
\text { is for the company with grades } \\
A A^{+}, A A \text {, and } A A^{-} \text {. Point } 3 \text { is for the } \\
\text { company with grades } A^{+}, A \text {, and } \\
A^{-} \text {. Point } 2 \text { is for the company with } \\
\text { grades } B B B^{+}, B B B \text {, and } B B B^{-} \text {. Point } 1 \\
\text { is for the company with grades } \\
B B^{+}, B B \text {, and } B B^{-} \text {. Point } 0 \text { is for the } \\
\text { company with grades } C \text { and } D\end{array}$ & Ordinal \\
\hline $\begin{array}{l}\text { Supervisory } \\
\text { board's size (SBS) }\end{array}$ & $\begin{array}{l}\text { The number of board commissioners } \\
\text { (NBC) at the end of } 2017\end{array}$ & Ratio \\
\hline $\begin{array}{l}\text { Supervisory } \\
\text { board's } \\
\text { independence (SBI) }\end{array}$ & $\begin{array}{l}\text { The number of people becoming the } \\
\text { audit committee at the end of } 2017\end{array}$ & Ratio \\
\hline $\begin{array}{l}\text { Audit committee } \\
\text { size (ACS) }\end{array}$ & $\begin{array}{l}\text { The number of people becoming } \\
\text { the audit committee at the end of } \\
2017\end{array}$ & Ratio \\
\hline $\begin{array}{l}\text { Profitability } \\
(R O A)\end{array}$ & $\begin{array}{l}\text { Return on assets (ROA) at the end } \\
\text { of 2017. The use of ROA follows } \\
\text { the study by Setyaningrum (2005), } \\
\text { Ashbaugh-Skaifea et al. (2006), } \\
\text { Hadianto \& Wijaya (2010), as well as } \\
\text { Elhaj et al. (2017) }\end{array}$ & Ratio \\
\hline
\end{tabular}

The variables related-data are analyzed by the ordered probit regression model. This model adopts the maximum likelihood technique to create the coefficients of regression (Ronning \& Kukuk, 1996) that make the highest probability of the outcome variable incidence (Widarjono, 2013). In addition, the regression model intended is in the first equation:

$$
\begin{aligned}
& B R_{i}^{*}=\beta_{0}+\beta_{1} S B S_{i}+\beta_{2} S B I_{i}+ \\
& +\beta_{3} A C S_{i}+\beta_{4} R O A_{i}+\varepsilon_{i} .
\end{aligned}
$$

In this model, the association between the unobserved $B R^{*}$ and the observed $B R$ is displayed in the second equation:

$$
B R=\left\{\begin{array}{l}
0 \text { if } B R^{*} \leq \mu_{1} \\
1 \text { if } \mu_{1}<B R^{*} \leq \mu_{2} \\
2 \text { if } \mu_{2}<B R^{*} \leq \mu_{3} . \\
3 \text { if } \mu_{3}<B R^{*} \leq \mu_{4} \\
4 \text { if } \mu_{4}>B R^{*}
\end{array}\right.
$$

Parameter $\mu$ shows the limit point to determine the area of the bond ratings. If $B R$ is equal to 0 and 1 , the companies having grade $\mathrm{C}$ and $\mathrm{D}$ is lower than $\mu_{1}$ and companies having grade $B B B^{-}$, $B B B$, and $B B B^{+}$is between $\mu_{1}$ and $\mu_{2}$, and so on.

Furthermore, the data are analyzed by the classification matrix to get the accuracy rate of categorizing all firm bond ratings (Gray et al., 2006). Mentioning Ghozali (2016), the accuracy rate is calculated by dividing the number of the correct prediction of the firm bond ratings with the number of the actual firm bond ratings.

\section{RESULTS AND DISCUSSION}

Table 2 demonstrates the number of companies based on the group of bond ratings. Overall, $94.4 \%$ of the companies becoming the samples dominantly own the investment grade $\left(B B B^{-}\right.$until $A A A$ ). Only $33.3 \%$ of companies with grade $A^{+}$, $A$, and $A^{-}$have the largest domination. Conversely, the smallest one comes from the companies with grade $\mathrm{D}$ and $\mathrm{C}(5.6 \%)$.

Table 2. Number of the companies based on the

\begin{tabular}{|c|c|c|c|c|}
\hline \multirow{2}{*}{$\begin{array}{l}\text { Bond- } \\
\text { rating }\end{array}$} & \multirow{2}{*}{$\begin{array}{l}\text { The code of } \\
\text { bond rating }\end{array}$} & \multirow{2}{*}{$\begin{array}{c}\text { Actual } \\
\text { observation }\end{array}$} & Valid & Cumulative \\
\hline & & & Percent & Percent \\
\hline$D, C$ & 0 & 2 & 5.6 & 5.6 \\
\hline $\begin{array}{l}B B B^{+}, B B B \\
B B B^{-}\end{array}$ & 2 & 5 & 13.9 & 19.4 \\
\hline$A^{+}, A, A^{-}$ & 3 & 12 & 33.3 & 52.8 \\
\hline $\begin{array}{l}A A^{+}, A A, \\
A A\end{array}$ & 4 & 11 & 30.6 & 83.3 \\
\hline$A A A, A A A^{-}$ & 5 & 6 & 16.7 & 100.0 \\
\hline Total & & 36 & - & 100.0 \\
\hline
\end{tabular}
group of bond ratings

Source: Modified output of EViews 6

Table 3 displays the descriptive statistics for supervisory board size $(S B S)$, supervisory board independence $(S B I)$, audit committee size $(A C S)$, and profitability $(R O A)$. The explanation is as follows:

a) for $S B S$, the number range of people becoming the board of commissioners is between 2 and 10 , with a mean of 5.4167 and a standard deviation of 1.90301;

b) for $S B I$, the range value of the independent commissioner's board ratio is between 0.14 and 0.60 , with a mean of 0.3720 and a standard deviation of 0.1100 ; 
c) for $A C S$, the number range of people appointed as an audit committee is between 2 and 6 , with a mean of 3.3611 and the standard deviation of 0.83333 ;

d) for profitability, the range value of $R O A$ is between $-24.48 \%$ and $16.48 \%$, with a mean of $3.0269 \%$ and a standard deviation of 0.6432 .

Table 3. Descriptive statistics of $S B S, S B I, A C S$, and $R O A$

\begin{tabular}{l|c:c:c:c:c} 
& \multicolumn{9}{c}{ Source: Output of IBM SPSS 20. } \\
\hline Variables & $\mathbf{N}$ & Min & Max & Mean & $\begin{array}{c}\text { Std. } \\
\text { deviation }\end{array}$ \\
\hline SBS & 36 & 2.00 & 10.00 & 5.4167 & 1.90301 \\
\hline SBI & 36 & 0.14 & 0.60 & 0.3720 & 0.11000 \\
\hline ACS & 36 & 2.00 & 6.00 & 3.3611 & 0.83333 \\
\hdashline ROA & 36 & -24.48 & 16.48 & 3.0269 & 6.43295 \\
\hline
\end{tabular}

The maximum likelihood technique makes the standard errors of the ordered probit regression model to follow the normal distribution. Therefore, the normality of standardized errors has to prove by using the statistical test of the Jarque-Bera (JB) (Widarjono, 2013). Figure 1 exhibits the normality test result. In this figure, the probability value of the Chi-square of the JB statistic is 0.627967 . Since this value exceeds the $5 \%$ significance value, the null hypothesis declaring that errors follow the normal distribution is not rejected and this accomplishes the requirement of this model.

After the normality condition is reached, estimating the coefficients of the ordered probit regression model is the following stage. Moreover, the estimation result is in Table 4.
Table 4. Estimation result of the ordered probit regression model: the impact of supervisory board size and independence, audit committee size, and profitability on bond rating

Source: Output of EViews 6

\begin{tabular}{|c|c|c|c|c|}
\hline Variables & Coefficient & $\begin{array}{l}\text { Std. } \\
\text { error }\end{array}$ & z-statistic & Prob. \\
\hline SBS & 0.541194 & 0.154466 & 3.503642 & 0.0005 \\
\hline SBI & 5.493061 & 2.233809 & 2.459056 & 0.0139 \\
\hline ACS & 1.415013 & 0.458790 & 3.084229 & 0.0020 \\
\hline ROA & 0.319446 & 0.081273 & 3.930522 & 0.0001 \\
\hline \multicolumn{5}{|c|}{ Limit points } \\
\hline LIMIT_2:C(5) & 6.454418 & 2.088065 & 3.091100 & 0.0020 \\
\hline LIMIT_3:C(6) & 8.869111 & 2.293683 & 3.866755 & 0.0001 \\
\hline LIMIT_4:C(7) & 10.75079 & 2.451098 & 4.386113 & 0.0000 \\
\hline LIMIT_5:C(8) & 12.77300 & 2.778341 & 4.597348 & 0.0000 \\
\hline $\begin{array}{l}\text { Pseudo } \\
R \text {-squared }\end{array}$ & 0.464717 & \multicolumn{2}{|c|}{ Akaike info criterion } & 2.009460 \\
\hline Schwarz criterion & 2.361354 & \multicolumn{2}{|c|}{ Log-likelihood } & -28.17029 \\
\hline $\begin{array}{l}\text { Hannan-Quinn } \\
\text { criteria }\end{array}$ & 2.132281 & \multicolumn{2}{|c|}{ Restr. log-likelihood } & -52.62691 \\
\hline LR statistic & 48.91325 & \multicolumn{2}{|c|}{ Avg. log-likelihood } & -0.782508 \\
\hline Prob(LR statistic) & 0.000000 & - & - & - \\
\hline
\end{tabular}

To test the null hypothesis, we compare each probability value of the $Z$-statistic of the regression coefficient of $S B S, S B I$, and $A C S$, and $R O A$ with a $5 \%$ significance value. If the probability value is lower than a $5 \%$ significance value, the null hypothesis is rejected. Instead, the alternative hypothesis is acknowledged.

In the statistical test, each research hypothesis in section 2, furthermore, will become an alternative hypothesis. From Table 4, the probability value of $Z$-statistic standing for SBS, SBI, ACS, and ROA is $0.0005,0.0139,0.0020$, and 0.0001 , respectively and each regression coefficient shows a positive

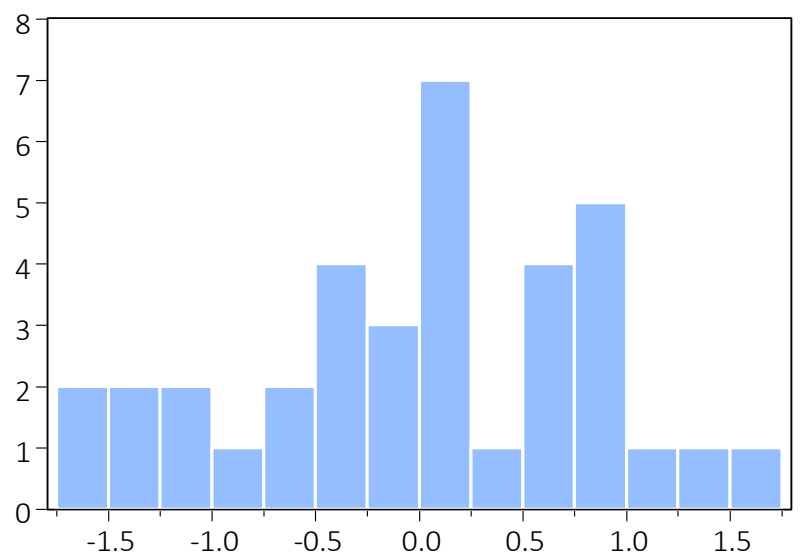

Series: Standardized Residuals

Sample 136

Observations 36

$\begin{array}{lr}\text { Mean } & 3.92 \mathrm{e}-10 \\ \text { Median } & 0.034948 \\ \text { Maximum } & 1.614894 \\ \text { Minimum } & -1.692246 \\ \text { Std. Dev. } & 0.835767 \\ \text { Skewness } & -0.263258 \\ \text { Kurtosis } & 2.414221 \\ & \\ \text { Jarque-Bera } & 0.930534 \\ \text { Probability } & 0.627967\end{array}$

Figure 1. The normality test result on residuals 
sign. This condition means research hypotheses one, two, three, and four are not rejected.

The test outcome of the first hypothesis pronounces that the supervisory board size has a positive impact on the company's possibility to get a high bond rating. This outcome confirms the resource dependence theory stating the big number of this board is needed to improve the performance of the company issuing the bonds so that its rating can go up. This positive impact verifies the research of Setyaningrum (2005), Aman and Nguyen (2013), Elhaj et al. (2017).

The test outcome of the second hypothesis pronounces that the supervisory board's independence has a positive impact on the company's possibility to get a high bond rating. The independent members of this board are important to protect the interest of bondholders by prohibiting the board directors to utilize money from the issued bond to be invested in the risky projects and paid as dividends. This positive impact verifies the research of Bhojraj and Sengupta (2003), AshbaughSkaifea et al. (2006), Grassa (2016).

The test outcome of the third hypothesis pronounces that the audit committee size has a positive impact on the company's possibility to get a high bond rating. By having many individuals in this position, the power of this committee becomes stronger to prevent the opportunistic actions of board directors. As a consequence, they improve the quality of financial reporting leading to an increase in bond rating status. This positive impact verifies the research of Setyaningrum (2005), Rianingsih (2009), Marfuah and Endaryati (2016).

The test outcome of the fourth hypothesis pronounces that profitability has a positive impact on the com- pany's possibility to get a high bond rating. It means that only companies with profits that can pay coupons for bondholders are needed to get a high grade of bond rating. Conversely, the companies with loss are assumed in financial distress and bankruptcy and get a speculative grade. This positive impact verifies the research of Setyangrium (2005), AshbaughSkaifea et al. (2006), Purwaningsih (2008), Hadianto and Wijaya (2010), Aman and Nguyen (2013), and Sunarjanto and Tulasi (2013).

Ideally, to make this quantitative research have a high external validity, the sample selection is needed to create the generalization (Hartono, 2012). To realize it, the samples have to be randomly grabbed from the population (Sugiyono, 2012). This research already meets this required condition because of the use of the simple random sampling method. Therefore, the utilization of 36 companies as the sample is totally sufficient.

To answer the second purpose of this study, the classification matrix of the ordered probit is used. This matrix, according to Gray et al. (2006), has the function to measure the accuracy rate of grouping the ratings based on the explanatory variables used. Based on the matrix presented in Table 5, the accuracy rate is $58.333 \%$. This rate is low and reasonable because this research focuses on theory testing and does not aim to make the prediction model that requires a high accuracy rate.

To get a high bond rating, the controlling shareholders are expected to increase the number of the supervisory board. The next question that may arise is the ideal maximum number of CB. To answer it, the research suggests that firms should have the number of CB in between 5 (rounded) as the average value and 10 as the maximum value (see Table 3).

Table 5. The accuracy of grouping bond rating based on SBS, SBI, ACS, and ROA

Source: Modified output of EViews 6.0

\begin{tabular}{|c|c|c|c|c|c|c|}
\hline \multirow{2}{*}{ Bond-rating } & \multirow{2}{*}{$\begin{array}{l}\text { The code of bond } \\
\text { rating }\end{array}$} & \multirow{2}{*}{$\begin{array}{c}\text { Actual } \\
\text { observation }\end{array}$} & \multicolumn{2}{|c|}{ Prediction result } & \multirow{2}{*}{$\%$ correct } & \multirow{2}{*}{$\%$ incorrect } \\
\hline & & & Correct & Incorrect & & \\
\hline$D, C$ & 0 & 2 & 2 & 0 & 100.000 & 0.000 \\
\hline$B B B^{+}, B B B, B B B^{-}$ & 2 & 5 & 3 & 2 & 60.000 & 40.000 \\
\hline$A^{+}, A, A^{-}$ & 3 & 12 & 7 & 5 & 58.333 & 41.667 \\
\hline$A A^{+}, A A, A A^{-}$ & 4 & 11 & 6 & 5 & 54.545 & 45.455 \\
\hline$A A A, A A A^{-}$ & 5 & 6 & 3 & 3 & 50.000 & 50.000 \\
\hline \multicolumn{2}{|l|}{ Total } & 36 & 21 & 15 & 58.333 & 41.667 \\
\hline
\end{tabular}


Regarding the bond rating being positively affected by the number of supervisory board and audit committee as well as the independent supervisory board, the investors who are interested in the bonds with low default risk are expected to choose the issuers having many independent supervisory and audit committee board members because they are effective to monitor the board of directors.

\section{CONCLUSION}

This research aims to prove and analyze the impact of supervisory board size and independence, as well as audit committee size on company possibility to get a high bond rating with profitability as the control variable and know the accuracy rate of grouping the firm bond ratings based on the explanatory variables used. Using 36 companies as samples, this research infers that supervisory board size and independence, audit committee size, and profitability have a positive impact on the company's possibility to get a high bond rating. It means that the monitoring of the supervisory board can improve the bond rating of companies when the board of directors can generate profits. In addition, the accuracy rate of grouping the bond rating is $58.333 \%$.

This research owns some limitations. Firstly, the accuracy rate of grouping the bond rating is as high as $58.333 \%$. It is due to the use of three main explanatory features of board governance. To make this rate increase, the next researchers are suggested adding the corporate governance index, institutional and managerial ownership, board duality, audit quality as the other main explanatory variables. Also, they are recommended using more other control variables, such as liquidity, leverage, size, interest coverage ratio.

Secondly, it only utilizes bond ratings resulted from PEFINDO, the domestic agency in Indonesia. As a consequence, it is impossible to compare the firm bond ratings in Indonesia with those of other countries in Southeast Asia. To compare the ratings among the countries, the next researchers are expected to search the same international agency assessing bond ratings. After that, they can use the countries as the moderating variable so that the theory related to bond rating determinant can be developed.

\section{REFERENCES}

1. Abor, J. (2007). Corporate governance and financing decisions of Ghanaian listed firms. Corporate Governance, 7(1), 83-92. https://doi. org/10.1108/14720700710727131

2. Altwijry, O. I. (2015). The Role of Corporate Governance and Ownership in Unconventional Bond Rating: Empirical Evidence from Companies Listed on Bursa Malaysia. Journal of Islamic Economics, Banking, and Finance, 11(2), 105-117. Retrieved from https://ibtra.com/pdf/journal/ v11_n2_article7.pdf

3. Aman, H., \& Nguyen, P. (2013). Does good governance matter to debtholders? Evidence from the credit ratings of Japanese firms. Research in International Business and Finance, 29, 14-34. https://doi. org/10.1016/j.ribaf.2013.02.002
4. Ashbaugh-Skaifea, H., Collins, D. W., \& LaFond, R. (2006). The effects of corporate governance on firms' ratings. Journal of Accounting and Economics, 42(1-2), 203-243. https://doi.org/10.1016/j.jacceco.2006.02.003

5. Bhojraj, S., \& Sengupta, P. (2003). Effect of corporate governance on bond ratings and yields: The Role of Institutional Investors and Outside Directors. The Journal of Business, 76(3), 455-476. https:// doi.org/10.1086/344114

6. Brealey, R. A., Myers, S. C., \& Allen, F. (2006). Corporate Finance (8th ed.). Singapore: McGraw Hill.

7. Easterbrook, F. (1984). Two Agency-Cost Explanations of Dividends. American Economic Review, 74(4), 650-659. Retrieved from https://www.jstor.org/ stable/ 1805130 ?seq $=1$
8. Ehrhardt, E. F., \& Brigham, M. C. (2012). Financial Management (13th ed.). Mason: South-Western Cengage Learning.

9. Elhaj, M. A., Muhamed, N. A., \& Ramli, N. M. (2017). The effects of board attributes on Sukuk rating. International Journal of Islamic and Middle Eastern Finance and Management, 11(2), 312-330. https://doi.org/10.1108/IMEFM-03-2017-0057

10. Ghozali, I. (2016). Aplikasi Analisis Multivariate dengan Program IBM SPSS 23. Semarang: Badan Penerbit Universitas Diponegoro.

11. Gitman, L. J., \& Zutter, C. J. (2012) Principle of Managerial Finance (13th ed.). Boston: Prentice-Hall.

12. Grassa, R. (2016). Corporate governance and credit rating in Islamic banks: Does Shariah 
governance matters? Journal of Management \& Governance, 20, 875-906. https://doi.org/10.1007/ s10997-015-9322-4.

13. Gray, S., Mirkovic, A., \& Ragunathan, V. (2006). The Determinant of Credit Ratings: Australian Evidence. Australian Journal of Management, 31(2), 333-354. https://doi. org/10.1177/031289620603100208

14. Hadianto, B., \& Wijaya, M. S. (2010). Prediksi Kebijakan Utang, Profitabilitas, Likuiditas, Ukuran, Dan Status Perusahaan Terhadap Kemungkinan Penentuan Peringkat Obligasi: Studi Empirik Pada Perusahaan Yang Menerbitkan Obligasi di Bursa Efek Indonesia. Jurnal Manajemen Teori \& Terapan, 3(3), 204-224. Retrieved from https://e-journal. unair.ac.id/JMTT/article/view/2403

15. Hanafi, M. M. (2017). Manajemen Keuangan (2nd ed.). Yogyakarta: Badan Penerbit Universitas Gadjah Mada.

16. Hartono, J. (2012). Metodologi Penelitian Bisnis: Salah Kaprah \& Pengalaman-Pengalaman (5th ed.). Yogyakarta: Badan Penerbit Fakultas Ekonomi Universitas Gadjah Mada.

17. Hartono, J. (2017). Teori Portofolio dan Analisis Investasi (11th ed.). Yogyakarta, Indonesia: Badan Penerbit Fakultas Ekonomi Universitas Gadjah Mada.

18. Husnan, S. (2009). Dasar-dasar Teori Portofolio \& Analisis Sekuritas (4th ed.). Yogyakarta, Indonesia: UPP AMP YKPN.

19. Kalay, A. (1982). StockholderBondholder Conflict and Dividend Constraints. Journal of Financial Economics, 10(2), 211-233. https://doi.org/10.1016/0304405X(82)90014-9

20. Marfuah, \& Endaryati, H. (2016). Pengaruh Good Corporate Governance dan Debt Maturity Terhadap Prediksi Bond Rating. Ekuitas: Jurnal Ekonomi dan Keuangan, 20(4), 434-454. Retrieved from https://ejournal.stiesia.ac.id/ekuitas/article/ view/45/42
21. Mariana, M. (2016). Pengaruh Mekanisme Corporate Governance Terhadap Peringkat Obligasi Yang Tercatat di Bursa Efek Indonesia Periode 2008-2010. Akrual: Jurnal Akuntansi, 7(2), 102-119. http:// dx.doi.org/10.26740/jaj.v7n2. p102-119

22. Mitton, T. (2004). Corporate governance and dividend policy in emerging markets. Emerging Markets Review, 5(4), 409-426. https://doi.org/10.1016/j.ememar.2004.05.003

23. Pfeffer, J. (1972). Size and composition of corporate boards of directors: The organization and its environment. Administrative Science Quarterly, 17(2), 218-228. https://doi.org/10.2307/2393956

24. Purwaningsih, A. (2008). Pemilihan Rasio Keuangan Terbaik Untuk Memprediksi Peringkat Obligasi: Studi Pada Perusahaan Manufaktur Yang Terdaftar di BEI. KINERJA, 12, 85-99. Retrieved from https://ojs.uajy.ac.id/index. php/kinerja/article/view/1392

25. Rianingsih, R. (2009). The Influence of Corporate Governance Practice Towards Credit and Bond Yields. Journal of Indonesian Economy and Business, 24(2), 249265. Retrieved from https://jurnal. ugm.ac.id/jieb/article/view/6328

26. Ronning, G., \& Kukuk, M. (1996). Efficient Estimation of Ordered Probit Models. Journal of the American Statistical Association, 91(435), 1120-1129. https://doi. org/10.2307/2291731

27. Sareen, R., \& Vij, M. (2015). Corporate Governance and Credit Ratings. Journal of Business Thought, 5, 103-125. Retrieved from http://www.informaticsjournals.com/index.php/jbt/article/ viewFile/21216/17434

28. Setyaningrum, D. (2005). Pengaruh Mekanisme Corporate Governance Terhadap Peringkat Surat Utang Perusahaan di Indonesia. Jurnal Akuntansi \& Keuangan Indonesia, 2(2), 73-102. http://dx.doi. org/10.21002/jaki.2005.11

29. Shleifer, A., \& Vishny, R. W. (1997). A Survey of Corporate
Governance. The Journal of Finance, 52(2), 737-783. https:// doi.org/10.1111/j.1540-6261.1997. tb04820.x

30. Sugiyono. (2012). Metode Penelitian Kombinasi (Mixed Method). Bandung: Penerbit Alfabeta.

31. Sukamulja, S. (2004). Good Corporate Governance di Sektor Keuangan: Dampak GCG Terhadap Kinerja Perusahaan (Kasus di Bursa Efek Jakarta). BENEFIT, 8(1), 1-25. http://journals.ums.ac.id/index.php/benefit/article/view/1193

32. Sunarjanto, N. A., \& Tulasi, D. (2013). Kemampuan Rasio Keuangan dan Corporate Governance Memprediksi Peringkat Obligasi Pada Perusahaan Consumer Goods. Jurnal Keuangan dan Perbankan, 17(2), 230-242. Retrieved from http://jurnal.unmer.ac.id/index. php/jkdp/article/view/742/404

33. Syakhroza, A. (2005). Corporate Governance: Sejarah dan Perkembangan, Teori, Model, dan Sistem Governance serta Aplikasinya pada Perusahaan BUMN. Jakarta: Lembaga Penerbit Fakultas Ekonomi Universitas Indonesia.

34. Tandelilin, E. (2010). Portofolio dan Investasi: Teori dan Aplikasi (1st ed.). Yogyakarta: Penerbit Kanisius.

35. Tjager, I. N., Alijoyo, A., Djemat, H. R., \& Soembodo, B. (2003). Corporate Governance: Tantangan dan Kesempatan bagi Komunitas Bisnis Indonesia. Jakarta: PT Prenhallindo.

36. Widarjono, A. (2013). Ekonometrika: Pengantar dan Aplikasinya disertai Panduan EViews (4th ed.). Yogyakarta: UPP STIM YKPN.

37. Zemzem, A., \& Zouhari, S. (2016). Japan's Corporate Governance Structures and Credit Rating. Asian Journal of Finance \& Accounting, 8(1), 195-211. https://doi. org/10.5296/ajfa.v8i1.9297 


\section{APPENDIX A}

Table A1. Names of the companies as the samples

Source: Reprocessed from IBMD 2018-2019.

\begin{tabular}{|c|c|c|}
\hline No. & Code & Names of the firms \\
\hline 1 & $\mathrm{ADHI}$ & PT Adhi Karya (Persero) Tbk. \\
\hline 2 & AGII & PT Aneka Gas Industri Tbk. \\
\hline 3 & AISA & PT Tiga Pilar Sejahtera Food Tbk \\
\hline 4 & AKRA & PT AKR Corporindo Tbk. \\
\hline 5 & AMRT & PT Sumber Alfaria Trijaya Tbk. \\
\hline 6 & CTRR & PT Ciputra Residence \\
\hline 7 & DILD & PT Intiland Development Tbk. \\
\hline 8 & EXCL & PT XL Axiata Tbk. \\
\hline 9 & FAST & PT Fast Food Indonesia Tbk. \\
\hline 10 & GIAA & PT Garuda Indonesia (Persero) Tbk. \\
\hline 11 & GWSA & PT Greenwood Sejahtera Tbk. \\
\hline 12 & IMPC & PT Impack Pratama Industri Tbk. \\
\hline 13 & INDF & PT Indofood Sukses Makmur Tbk. \\
\hline 14 & ISAT & PT Indosat Tbk. \\
\hline 15 & JPFA & PT Japfa Comfeed Indonesia Tbk. \\
\hline 16 & JSMR & PT Jasa Marga (Persero) Tbk. \\
\hline 17 & KAll & PT Kereta Api Indonesia (Persero) \\
\hline 18 & LTLS & PT Lautan Luas Tbk. \\
\hline 19 & $\mathrm{MAPI}$ & PT Mitra Adiperkasa Tbk. \\
\hline 20 & MDLN & PT Modernland Realty Tbk. \\
\hline 21 & MEDC & PT Medco Energi Internasional Tbk. \\
\hline 22 & PANR & PT Panorama Sentrawisata Tbk. \\
\hline 23 & PIGN & PT Pelabuhan Indonesia I (Persero) \\
\hline 24 & $\mathrm{PIHC}$ & PT Pupuk Indonesia (Persero) \\
\hline 25 & PJAA & PT Pembangunan Jaya Ancol Tbk. \\
\hline 26 & PPLN & PT Perusahaan Listrik Negara (Persero) \\
\hline 27 & PPNX & PT Perkebunan Nusantara X \\
\hline 28 & PPRO & PT PP Properti Tbk. \\
\hline 29 & SMAR & PT Sinar Mas Agro Resources And Technology (Smart) Tbk. \\
\hline 30 & SMGR & PT Semen Indonesia (Persero) Tbk. \\
\hline 31 & SMRA & PT Summarecon Agung Tbk. \\
\hline 32 & STTP & PT Siantar Top Tbk. \\
\hline 33 & TAXI & PT Express Transindo Utama Tbk. \\
\hline 34 & TBIG & PT Tower Bersama Infrastructure Tbk. \\
\hline 35 & TINS & PT Timah Tbk. \\
\hline 36 & TLKM & PT Telkomunikasi Indonesia (Persero) Tbk. \\
\hline
\end{tabular}

